UDC 536. 52:535.232.6

論説

\title{
高速ふく射棓の試作
}

\section{Development of High speed Radiation pyrometer}

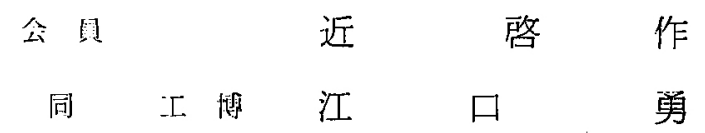

\section{1. 緒 言}

高温の物体が放出するふく射エネルギーを利 用した非接触温度測定の方法は熱しし刘などの接 触法に比して測定精度は多少少るが，(1)その簡 便さ，(2)被测温体と感温部が㒹接接触して $\mid$ i $\mid$ 一 温度になる必要がない，(3)移動する物体でも测 定できるなどの利点から，従来から光离温部， ふく射高温訃，光電管高温計，鼠高温部として 多く使用されてきた。しかるに最近の一般工業 技術のレベルアッブにともなってふく射高温計 も(1)測定精度の向上のみならず，(2)応答特性の 速いものや，(3)小ふく射体の測定可能なもの， (4)自動記録できるものなどが要求されるように なった。ての要求に応えるものとして最近では 感温部にフォトダイオードやボロメータ京使北 したもの，あるいは 2 波長の強度比在測定して

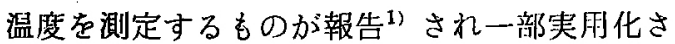
れつつある。

筆者らは最近のエレクトロニクスの産物であ るシリコン・フォトトランシスダ) の光に対し 非常に応答の速い特性 $(0.001 \mathrm{sec})$ と最高波長 感度 $(0.95 \mu)$ 亿着目し，阔トランシスタを感 温部とし簡単なブリッシ回路を便用したふく射 高温計を試作し，高速温度検出器としての可能 性の実験を行ない，その実用化をはかった。

こてでは今回試作した高速ふく射計の特性な らびに実地試験の結果化ついて報告する。

\section{2. 高速ふく射計の構成}

今回䳝作した高速ふく射計の外観および原理 図を写真 1 なら゙に第 1 図に示す。ての装置は 受光部，抵抗ボックス，記録計にわか扎でうり， 受光部はレンズ系と感温部ならびに絞り機掅， 抵抗ボックスはブリッシ朋抵抗と定霞氐雹源 で，記録計は山武八ネウェル製高速霞子管式 $\mathrm{mv}$ 計を便用した。ブリッシ回路には感温朋フ ォトトランジスタのはかに，6う1コ问種類の フォトトランジスタを使用し，てれには前面に 絞りが取りつけられ感温フォトトランジスタと 间じ位置に設置されて入射光の一部が入射する ようになってわり周罒温度の上昇による指示の 変動を防止するための補償をなしている。

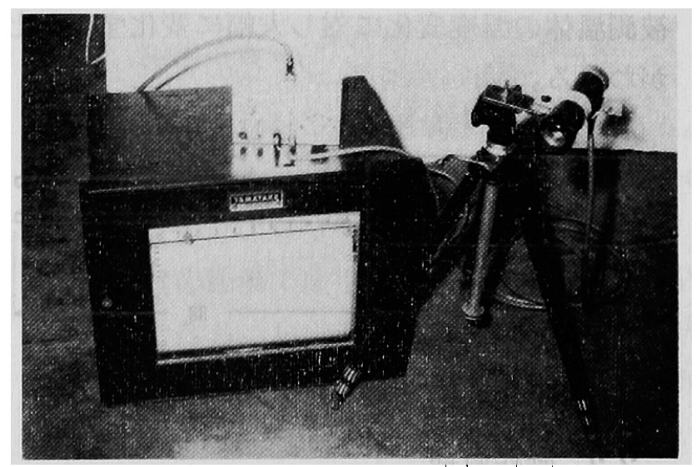

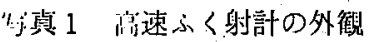




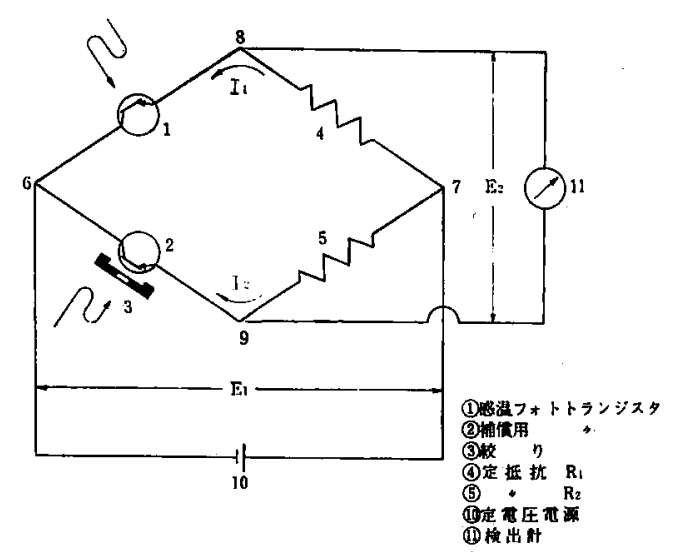

第 1 図槀速心く射計原理図

\section{1 フォトトランジスタの特性}

フォトトランシスタに光をあてるとその電気 的特性が変化するが，その特徽として応答時 間, 剑度, 波長分布が非常に優れている。今回 試験に使用した東芝製シリコン・フォトトラン シスタ OS17 について，その特性を東芝半導体 八ンドブックならびに実測結果によりそれぞれて 第 2 図 第 6 図, 第 1 表に示す。応答時間 0.001 sec，波長感度は第 3 図に示すように $0.95 \mu の$ 赤外部に最大值をもっており，その他の入射光 はカットされた状態になるので温度测定上非常 な便宜をむたらしている。周囲温度の上昇によ る暗電流変化は第 4 図に示すようにゲルマニウ ム・フォトトランジスタに比して小さく高温ま で安定に使用できる。また第 5 図, 第 6 図に温 度(入射光)に奶する電流，電王特性を示すが, これによりフォトトランジスタに流れる電流は 被測温体の温度変化に対し大幅に変化するとと がわかる。

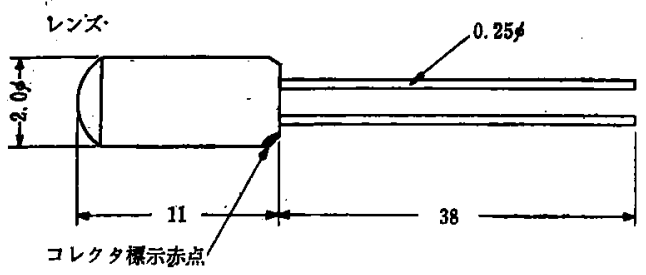

第2図 フォト・トランシスタの外形図

\section{2 動作原理}

感温部ならびに補償用フォトトランジスに は校りを通して被测温体からの入射光があれ ば，第 1 図に示したブリッシ回路には入射光に

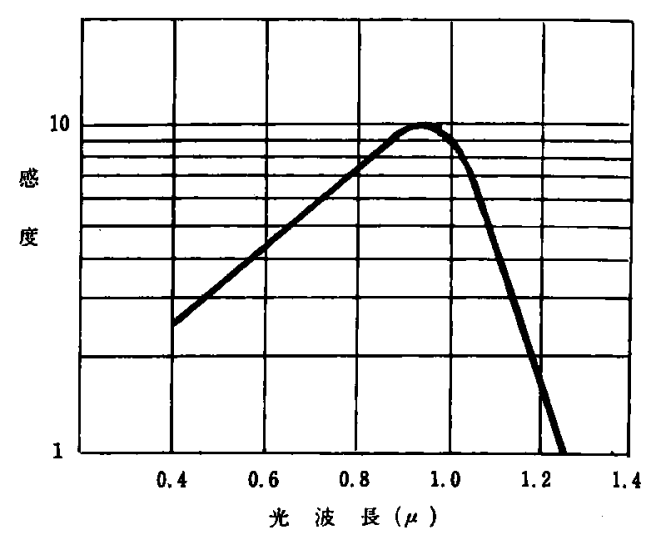

第 3 図 波 長感度 特性

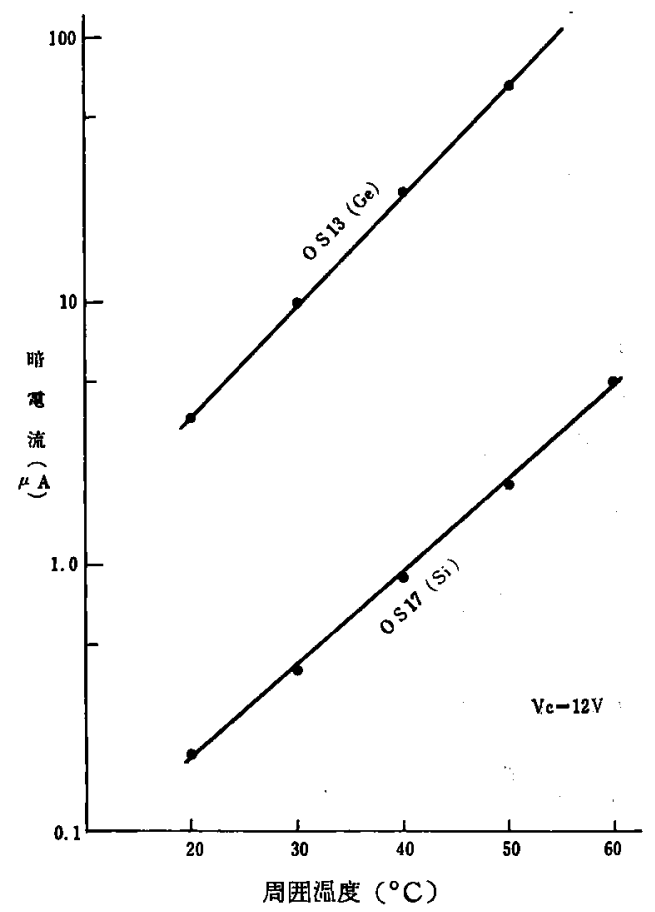

第 4 図 愔䨘流一周国温度特性:

（第 3，4図は東芝米導体ハンドブックによる）

対応した I1，I2 の䨘流が流孔端子8，9間に不

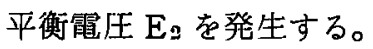

$$
\text { すなおち } \mathrm{E}_{2}=\mathrm{I}_{1} \mathrm{R}_{1}-\mathrm{I}_{2} \mathrm{R}_{2}
$$

この出力は $\mathrm{R}_{1}$ ， $\mathrm{R}_{2}$ の值を適当に選ぶことによ り見かけ上低インピーダンスにて直接霞子管式 記録計に接続が可能である。

倹定炉を使用して温度とふく射計の起電力の 相関を必要な温度範囲にわたってとっておけば 未知の被測温体の温度をふく射計の指示汃ら知 るととがでるる。第 7 図はとのふく射計の起雪 


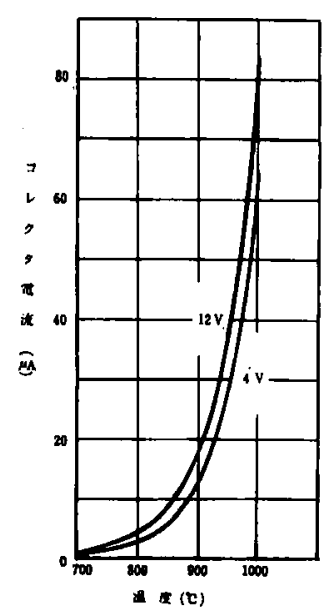

第 5 図 温度一電流特珄

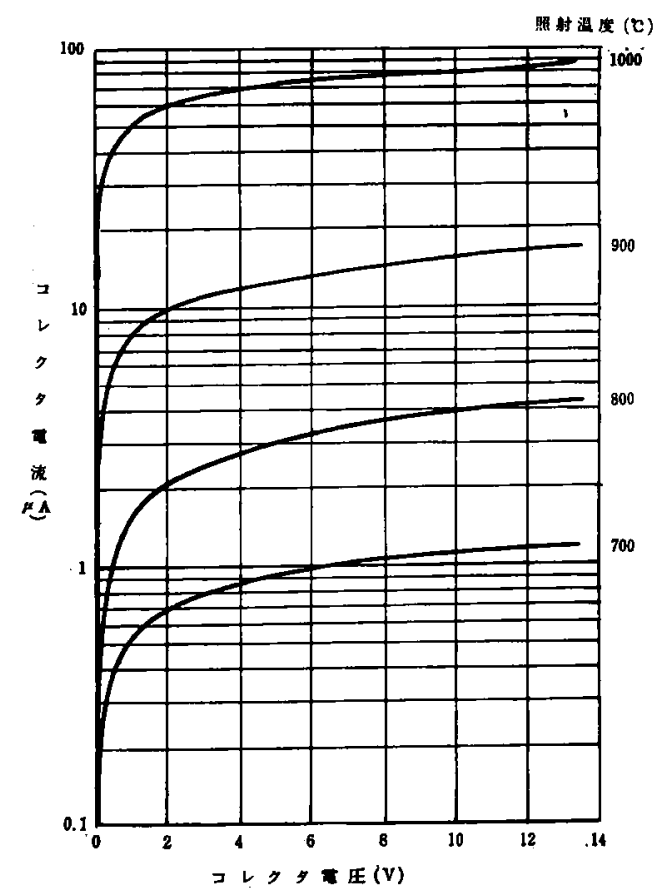

第 6 図 温度一䉓流，電任特性:

第 1 表 OS17の定格

(東芝半導体ハンドブックによる)

\section{最大定格（周囲温度 $25^{\circ} \mathrm{C}$ )}

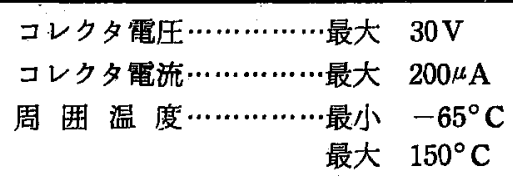

電気的特性（周囲温度 $25^{\circ} \mathrm{C}$ )
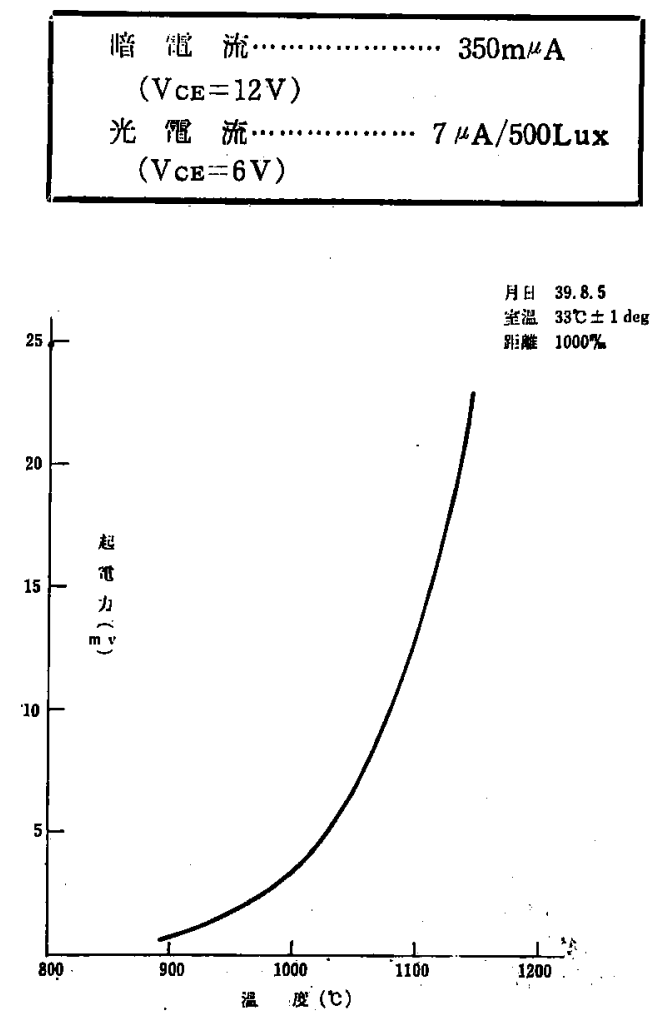

第 7 図起電力一温度耝線

力一温度曲線の一例を示す。

\section{3 レンズ系}

対物レンズは直径 $30^{m}$ 甲 $\varnothing$, 焦点距離 $130 \%$ の ものを主として使用した。被測温体の測定可能 最小面積は距隻により異なる。これを一般に距 歓係数であらわしており次のような関係にな る。

$$
\text { 距離係数 }=\frac{\text { 許容最大測定距離 }}{\text { 被測面の直径 }}
$$

試験に件用したレンズの距離係数は40である。 距離係数の大小は実際現場で使用に当ってその ふく射計がどの程度の大きさの被測温体に対し どれだけの距離で使用できるかを決定する重要 な要素となる。レンズの径は被測温体が全面視 野に入ることが望ましいので被測温体が細物の 場合，レンズの径の小さいものを使用した。な お，とのような場合でも被測温体の振動が少な く入射面皘がはとんど一定なら多少精度は低下 するが，測定は実用上可能である。 


\section{4 校作方法}

高速ふく射計の校正方法としては検定炬に東 京精工笠高温用黒体炉を使用した。これの規定 の使用温度範罒は $1000 \sim 2000^{\circ} \mathrm{C}$ であるが, 使 宜上 $880^{\circ} \mathrm{C}$ 近くまで使用した。乙れの調節精度 は土 $3 \mathrm{deg}$, 以内である。ふく射計は距離係数 以内の位置に設置し, 黑体炉が設定温度に到達 してから10分保持後, 校正を開始した。黒体炕 標的の温度は光高温計によって測定した。され による校正の精度は $1000^{\circ} \mathrm{C}$ 以上士 $5 \mathrm{deg}$ であ る。黒休炉外観を写真 2 亿示す。

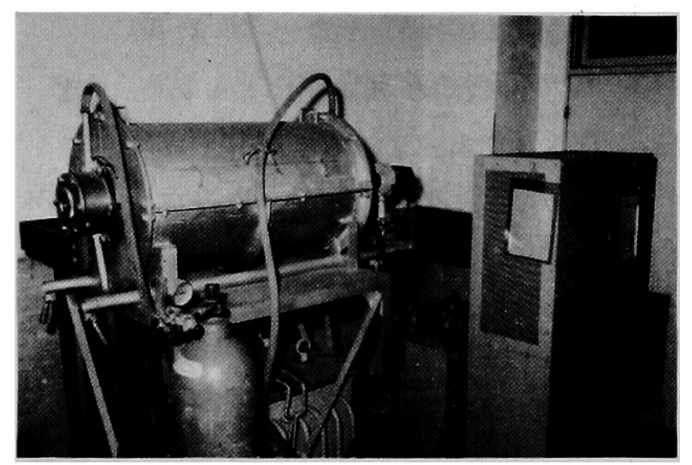

写真 2 黒体炉外篧

\section{3. 高速ふく射計の特性試験}

フォトトランジスタを利用して, 例えば自動 開閉屝に使用する場合は単に on-off 信号で足 り, この場合の特性の安定度, 周囲温度の影響 などはさして問題にならない。しかしてれを温 度検出端として使用する場合, その安定度, 精 度, 経年変化, 応答速度, 周囲温度の影響, 周 用の明るさなぞが当然問題になるのでそれにつ いてそれぞれ試験を行った。

\section{1 精度 (再現性) ならびに経年変化}

この場合, 精度は最初の温度一起電力曲線に 奶し再び校正を行った際のふく射計の指示のパ ラッキ, 経年変化としては或る時期を経過後最 初の温度一起電力曲線に対した指示のバラッキ を見た。この時の測定条件はできるだけ闹一に して行った。この結果を第8図, 第9図に示 す。これによれば高速ふく射計の精度は良好で 哭差は測定誤差以内である。

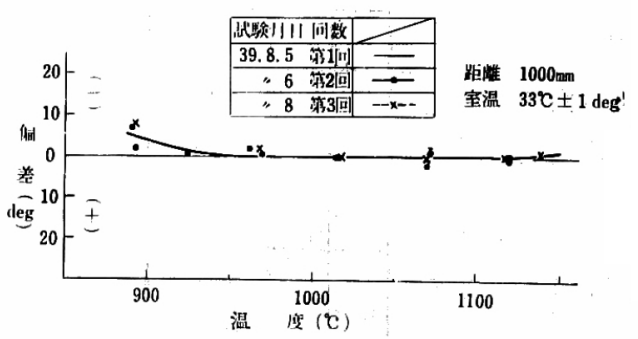

第 8 図精度 陚験

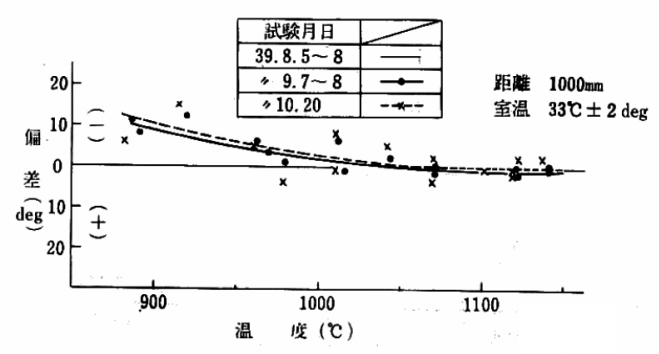

符 9 戍経作変化

経年変化としては第 9 図に示すように低温部 に指示のずれが見られたが，てれはふく射目盛 の特徵として低温部になるほど目盛幅がせまく なり，校正精度も㯖くなるのでての程度で経年 変化とは、難く,なお今後定期的にチェック して行きたい。

\section{2 安 定 度}

安定度については黒体炉を一定温度に保持し 連続照射試験を行った。この時の周囲温度は $22^{\circ} \mathrm{C} \pm 1 \mathrm{deg}$ である。ふく射計の起電力は山 武製電子管式記録計 $(0 \sim 50 \mathrm{mv})$ で連続測定し た。この絬果を第10図に示す。これによれば連 続的に測定しても高速ふく射計の指示の変動は ほとんど見られず安定度は良好である。

\section{3 応答速度}

フォトトランジスタ応答速度は通常 0.001 sec と云われているが，温度計としては単に入 射した信号を検出するだけでなく，絶刘值を測 る必要があるのでて机を確めるため次のような 武験を行った。斌験方法としては被測温体の温 度を一定に保持し，高速ふく射䛎の齐物レはズ の手前にキ+ノンカメラのフォーカルプレーン ・シャッターをおいて絞り 1.8 開放にて, シャッ 
タ一速股を Bから 1/500sec まで段階的に変光 机をボラロイドカメラで摄影した。てれの測定 て試験を行った。この時の起電力 (mv) 一時間＼cjkstart結果を第11图に示す。これによればBから1/60 (sec) の測定はシンクロスコープを使用し，こｓec まで起雪力は最大值に達しており $1 / 125 \mathrm{sec}$

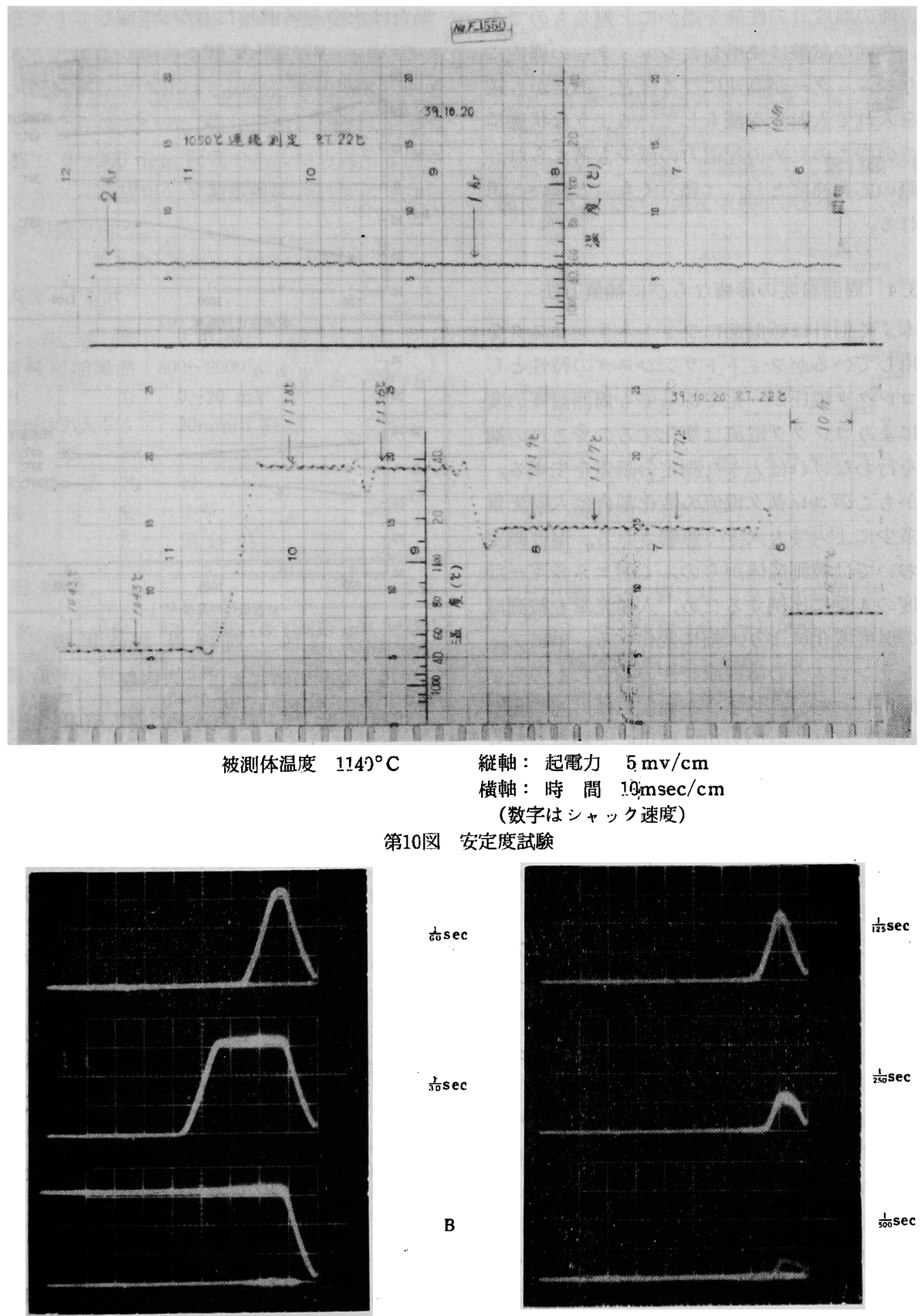

第 11 図 カメラ・シャッターによる応答速度試験 
で最大做の約 $80 \%$ までに達したにすぎない。こ の結果から兒れば応答速度は約 $1 / 100$ secである が、この程度でも実网上は充分であり，従来の この種の温度計の性能を遥かに上迴るものであ る。今回の試験は使用したシャッターの機能に よりシャッターが高速になるはど，あたかる絞 りを人れて入射光を堿らしているような状態に なるのでてのための起電力の減少も替えられ， 実際の応答速度としては恐らくもっと速いと思 われる。

\section{4 周囲温度の影響ならびに補償方法}

本ふく射計は感温部にフォトトランジスタを 使用しているがフォトトランジスタの特性とし てコレクタ電圧が一定であっても周国温度の変 動によりコレクタ電流は変化するのでてれの補 償を行わなければ大きな測定の誤差を生ずる。 しかもとのコレクタ電流の変化割合は入射光量 の多少によっても大きく影響される。温度测定 においては被測温体からのふく射エネルギーは 温度の 4 乗に比例するため, 入射光量も被測温 体の温度変化により大幅に変化する。単にフォ トトランジスタの暗電流特性の揃ったものを 2 コ使用し，そのうち1コを補償用に外部の光か ら遮蔽しブリッジの対辺に使用して補償を行う 方法は入射光量の変化の幅の少ない所では有数 であるが，温度測定のように入射光量が大愊に 変化する場合はそのまま使用できない。すなわ ち周囲温度の補償は入射光量にも対応してなさ れる方法を選ばなければならない。

本ふく射計はこれを解決するため補償用つォ トトランジスタには感温フォトトランジスタと 入射光量一コレクタ電流特性がはぼ同じかやや 大きいもので, 周囲温度変化によるコレクタ䨡 流変化のより大きいものを選び，ての手前に絞 り機構を設けて入射光の一部が入射するように した。すなわち，上記方法によって周囲温度変 化による両者のコレクタ電流変化分としては, ほば等しくなるように絞りの量を選んでおけば 変化分は相殺されるので，てれによってふく射 計の指示はあまり影響を受けず，被測温体の温 度を知ることができる。第12図に周囲温度の影

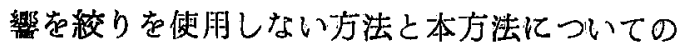
椡定結果を示す。現場では測定時期，場所によ り周罒温废が $40^{\circ} \mathrm{C}$ 以上の場合もあるが，その 場合は水冷を考虑した方がよい。

紋りを使用しないカ治
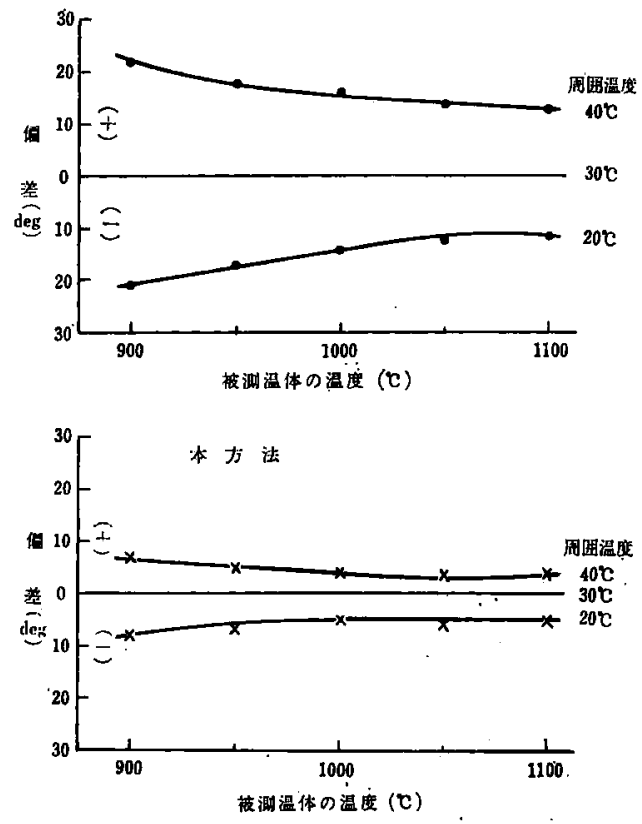

第 12 図猿囲温度の影響

3.5 周四の明るさによる影響

工場現場では一般に通常の室内照明に比して ほとんどの場合暗く，乙れは高速ふく射計を使 雨する場合，他の入射光の影響を受けないので むしろ有利である。些際に通常の室内照明と照 明なしの相当暗い場合で比較して見たがふく射 計の指示に影響は見られなかった。てれはつォ トトランジスタの最大感度波長が $0.95 \mu$ の赤外 部にあるためと思われる。ただ直射光（例，日 光）が直接被測温体に当るとか，ふく射計に被 測温体以外の強い光が入るととは当然避けなけ ればならない。

また水蒸気の影響も全ふく射温度計にくらべ れば赤外部は水蒸気に余り吸収されないので少 ないが，やはり感度は低下するので避けた方が 良い。

\section{4. 高速ふく射計の性能}

試作した高速ふく射計ならびに同時を慗使用し た記録計の性能を第 2 表に示す。 
晒和 40 年 9 月（1965) )

今回は㬰网上, 高速電子管式記録計を使用し たため記録計のペンスピード（0.25sec）が棒測 時の応答速度である。被測温体の溫度が低い場 合はブリッシ国路の R1，R2の抵抗值を大きく することにより出力を大きくするてとができ る。抵抗ボックスにはこのための切換スイッチ が取付けられている。また目盛レンジは不平等 目盛で 0〜300 deg 程度であるため適当な倍率 フイルターを健用して被測温体の温度によりレ ンジ切换を行う。

第 2 表 高速ふく射計の性能

高速ふく射計

\begin{tabular}{|c|c|}
\hline $\begin{array}{l}\text { 応 答 速 廈 } \\
\text { 測温可能範国 }\end{array}$ & 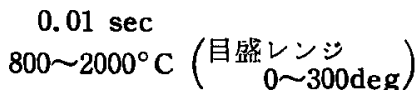 \\
\hline 出 力 & $0 \sim 20 \mathrm{mV}$ \\
\hline 被測体の大きさ & $20 \mathrm{~mm}$ 巾上 \\
\hline 光 学 & レンズ \\
\hline 距 觹 係 & 40 \\
\hline 精 & $1 \%$ \\
\hline 校 & 黒体炉 \\
\hline
\end{tabular}

記 録計

\begin{tabular}{|c|c|c|}
\hline 名 & \multicolumn{2}{|c|}{ 電于管式自動平衝形 $\mathrm{mV}$ 記録計 } \\
\hline 製作所, 型式 & 山武製 N153×16 & \\
\hline 目 & $\begin{array}{l}0 \sim 10 \mathrm{mv} \\
0 \sim 20\end{array} \quad$ （最小目盛 & $\left.\begin{array}{l}0.05 \mathrm{mv} \\
0.1\end{array}\right)$ \\
\hline $\begin{array}{l}\text { フルスケールペ } \\
\text { ンスピード }\end{array}$ & $0.25 \mathrm{sec}$ & \\
\hline 記 録 速 & $25.4 \mathrm{~mm} / \mathrm{sec}$ & \\
\hline 記 録 紙 ウ & $279.4 \mathrm{~mm}$ & \\
\hline 精度 & $\frac{1}{4} \%$ & \\
\hline
\end{tabular}

\section{5. 実地試呀}

哭地訊䤅としては大同紫鋼知多工場ならびに 星崎工場圧延現場に抢いて高速で移動中の圧延 鋼材で武験を行った。この結果従来測定困難で あった，

（1） 1 本の鋼材の各部の温度分布

(2) 各本闑の温度差

が明らかとなった。実施例として第13囯〜第15 図に示す。これの測定条件は次の通りである。

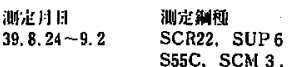
S55C, SCM 3, SCM 4

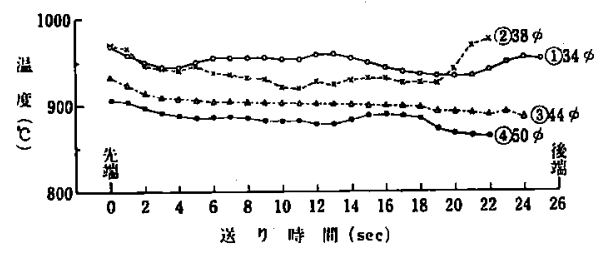

第13図 知多工場中小型压延 各鈴種法別仕上温度

測定 位㯰 ; 仕上ロール直後

"距離; $0.4 \sim 1.5 \mathrm{~m}$

被測温体巾; 10 65 ${ }^{m} \phi$

" 温度; $800 \sim 1000^{\circ} \mathrm{C}$

" 速度; $3 \sim 5 \mathrm{~m} / \mathrm{sec}$

上記仕上温度測定の場合被測温体が小さいた め, 特にこえによる高速ふく射計の周囲温度上: 昇は見られなかった。

第 14 図星崎工場 大型任延, 本間仕上温股差

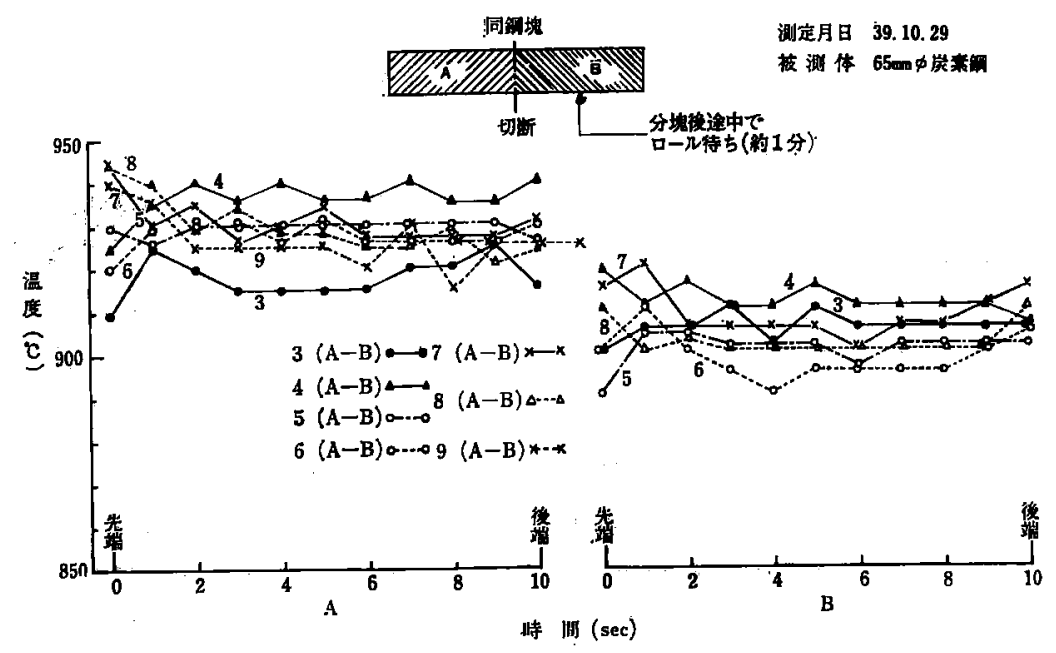


(HR14Fバルブ鋼No. 51 9.75m. $/ \mathrm{m} \Psi)$

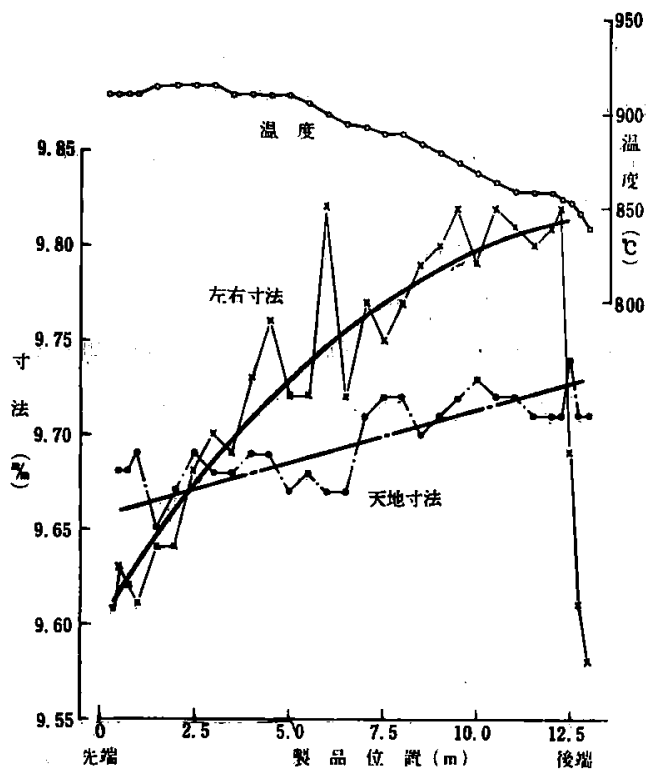

第15図 星崎工場, 小型压延

甘二上温度と寸法の関係の一例

測 定 条 件

\section{6. 考 察}

分回 試作した高速ふく射計の特性試験およ び垷場における実地試験の結果

(1) 当初の目的である高速温度検出器として 充分使用できることが確認された。

（2）精度は低温部 $\left(900^{\circ} \mathrm{C}\right.$ 以下) において校 正の精度，温度計の目留幅がせまくなることの ため多少低下するが $900^{\circ} \mathrm{C}$ 以はにおいては 1.0 。を保証できる。

(3) 本ふく射計はさきに述べたように $0.95 \mu$ の単波長に近似したもので㭘出するため輝度温 度計の特性も持っており，したがって全ふく射 温度計に比して，ふく射率の補正量は約 $1 / 3$ で 㨈む。しかも自動記録が可能である。実際，加 熱された鋼片を光高温計と同時にチェックした 時でも両者の測定值は土10deg 以队で良い一致 を見た。光高温計で鎆片を測定した時のふく射 染は 0.8 0.9 程度と言われている。これを温 度換算した補正值は $1100^{\circ} \mathrm{C}$ で19９deg，800 Cで 11〜 5 deg である。従来光高温計を $1000^{\circ}$ $\mathrm{C}$ 前後で使用する場合はこの補正は現場的には ほとんど実施していない。今後本ふく射計の精
度问上と共にふく射栾による影響白さらに良く 検討して見たい。

（4）測温下限は $800^{\circ} \mathrm{C}$ 程度がての檢出器の限 度である。

（5）現場で連続使朋する場合，測定箇所，時

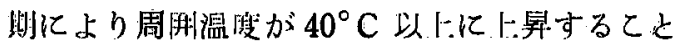
も考元られるならば水彾を考虑しなければなら ない。

（6）被測温体の振動も特に細物の場合安定し た測定を困難にするが，口ール直後を選ぶと か，測定位置を適当に選定することによってほ とんど避けることができる。

（7）感温部の経年変化についてはさらに長期 閐定期的にチェックしてみる必要があるが，一 般のトランシスタ類が従来の真空管にとって代 ってきておる現状からも，使用采件さえ良けれ ば相当長期間使用できると思われる。

（8）圧延工場における鋼材の端面割れ調查の ための冷却速度測定とか，仕上温度と成品寸法 の相関調查などによって高速ふく射計の有用性 が認められた。例元ば第15図に一例を示した大 闹製銅星崎工場，小型圧延におけるバルブ鋼の 仕上温度と留品寸法の調查では天地寸法（危险 率 $1 \%$ ）だけでなく左右寸法についても伦除率 $5 \%$ で仕上温度との相関が認められ，寸法公素 の敩しいものについては本間，本内の温度差少 大きいと什上:温度のみにより公差内の相当のバ ラッキ量を示すことが発見され対策が市てられ た。

\section{7. 結 言}

本ふく射計の特徵を要約すれば

(1) 即応答性で自動記録ができること。

（2）感温部にフォトトランシスタを使用し， さらにもう 1 ケのフォトトランシスタをその手 前に絞りを設置し広範围の入射光に対し温度補 償を有効に行わしめることができること。

（3）製作貿が非常に安いこと。

（4）ふく射率の禣正が少なくて阂むことであ る。

（以下 261 頁へ続く） 
いう久点がありますが，ての磁石も间様で，む しろ、なおやや脆い傾向がありますのでで利用 に際してで注意をお願いします。

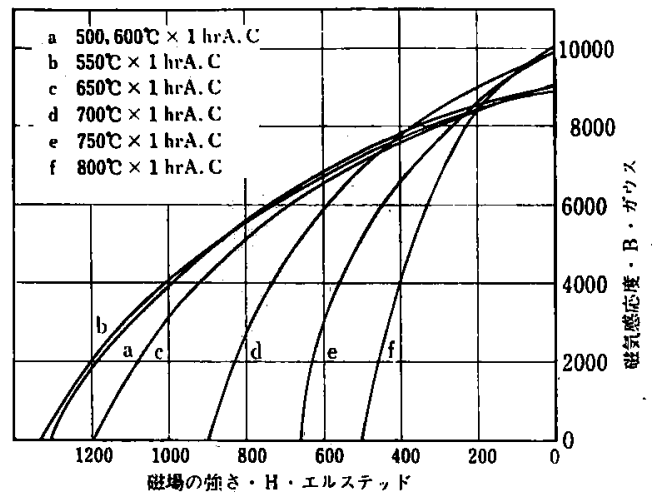

第 7 図 加熱による減磁

\section{4. 仕様}

ご注文にあだ，他のアルニコ磁石の場合と 阔様に下記についてで指示下さるようお願い致 します。

（1）形状，寸法および寸法公差

(2) 磁石の種類, 名称

（3）磁性（開路磁束）

(4) 磁化方向

(5) 許されれば用途

（6）その他製造上の注意事項

(226頁より続く)

現在，すでに圧延工場などにおける温度管理 は央際の圧延中の温度をチェックして加熱焒な どの制御を行う方向に向っており，乙の場合高 速ふく射計は管理計器としてますます重要性を 帯びてくるであろう。

最後に本研究にあたりで指導，で鞭達頂いた 当社中央研究所長浅田千秋工学博士ならびに現 場実験に際し御協力頂いた知多工場技術課，王
延課，星崎工場王延課の諸氏に深く感謝致しま す。

\section{【引 用 文 献了}

1）高田誠二：熱処理， 4 (1964）1，71

2）真芝商覃編：東芝半導体ハンドブック

(1962) 1.9532 